\title{
Abiotic factors influencing the occurrence of Salicornia europaea in West Estonia
}

\author{
*Piotr Hulisz, **Tiina Elvisto, ***Mirosław T. Karasiewicz, ****Agnieszka Piernik \\ *Department of Soil Science, Institute of Geography, Nicolaus Copernicus University, \\ Gagarina 9, 87-100 Toruń, Poland, e-mail: hulisz@umk.pl, \\ **Institute of Mathematics and Natural Sciences, Tallin University, 25 Narva Rd, 10120 Tallin, Estonia, \\ ***Department of Geomorphology and Palaeogeography of the Quaternary, Institute of Geography, \\ Nicolaus Copernicus University, Gagarina 9, 87-100 Toruń, Poland, \\ *****Laboratory of Ecological Modelling, Institute of Ecology and Environment Protection, \\ Nicolaus Copernicus University, Gagarina 9, 87-100 Toruń, Poland
}

\begin{abstract}
Summary. The occurrence of Salicornia europaea in Western Estonia (Kassari and Topu bays) is the result of complex processes occurring in the Baltic coastal zone and conditioned by such abiotic factors as topography, lithology, hydrogeology and climate. This is reflected by very high salinity level of groundwater and soils.
\end{abstract}

Key words: Baltic Sea, Salicornia europaea, salt marshes, seawater, soil salinity.

\section{Introduction}

Common glasswort (Salicornia europaea) is one of the most salt tolerant plants, hence it can be used as an indicator of the high soil salinity level. The Baltic Sea is one of the largest brackish seas in the World. Therefore, there are not so many Salicornia europaea stands in Baltic coastal zone. Most glasswort stands were described in Estonia (Kukk \& Kull 2005). Generally, the occurrence of Salicornia europaea in these places seems to be not typical and not related to the salinity gradient of the Baltic water. The aim of this study was a quantitative and qualitative characteristics of the environmental factors determining the occurrence of Salicornia europaea in the coast of Kassari and Topu Bays (West Estonia).

\section{The study area}

Kassari Bay and Topu Bay are relatively isolated from the Baltic Proper and other regions of the Väinameri. The bottom of these bays is relatively flat. According to Suursaar et al. (2000) the salinity of seawater is typically between 6.0 and $6.7 \%$. The annual amplitude of the mean sea level is $14 \mathrm{~cm}$ at Pärnu. There is a pattern with high mean sea level in the summer, maximum in autumn-winter and minimum in late winter or spring. On the West Estonian coast there is a strong seasonality wind pattern where SW winds are prevailing (Suursaar 2010, in press).

\section{Research methods}

The research was done in August 2010. Figure 1 shows the location of study sites (A - Põgari-Sassi, Topu Bay, 
B - Kassari Bay), which are flooded during high water levels of the Baltic Sea. In each site temperature and electrical conductivity (EC) were measured along the soil, surface seawater and groundwater transects (TDR and conductometric methods). Soils were sampled according genetic horizons for grain size distribution and organic matter content analysis. The combined (sieve and laser) method was used. Organic matter content was determined by loss on ignition at $550^{\circ} \mathrm{C}$. To describe the vegetation phytosociological relevés were taken according to the Braun-Blanquet method (Braun-Blanquet 1964) in the soil measurements points. The size of each relevé were relatively small to represent soil conditions $(3 \times 3 \mathrm{~m})$. Nomenclature follows Mirek et al. (2002).

\section{Results and discussion}

The study sites were characterized by the occurrence of surface bipartite deposits consisted of marine sediments overlaying moraine till. Results of grain-size distribution analyses allowed to determine the thickness of the marine sediments. It ranged from 5 to $23 \mathrm{~cm}$ in Põgari-Sassi and from 29 to $47 \mathrm{~cm}$ in Kassari, clearly increasing towards the bay. The terrain was flat with very slight inclination towards the sea basin, which was very shallow. For example, in site B water depth in the distance of $600 \mathrm{~m}$ from the shoreline was only $55 \mathrm{~cm}$. It suggested that there was a lodgment till in the base (Kalm \& Kadastik 2001). Fig-

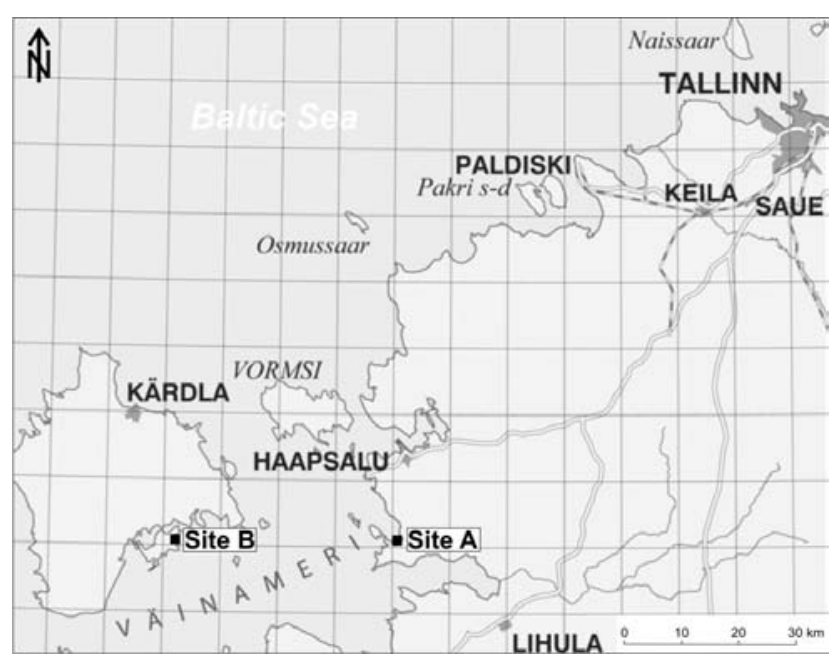

Figure 1. Location of the study sites

ure 2 shows the relation between sea water temperature and salinity measured in transects. Thermal conditions in the coastal zone and within a few hundred meters from the shore were clearly differentiated (respectively $26.9^{\circ} \mathrm{C}$ and $22.6^{\circ} \mathrm{C}$ - site $\mathrm{A} ; 30.5^{\circ} \mathrm{C}$ and $24.3^{\circ} \mathrm{C}$ - site $\mathrm{B}$ ). The variability of EC values showed similar trend (from 13.0 to $11.2 \mathrm{dS} \cdot \mathrm{m}^{-1}$ - site A; from 14.1 to $11.1 \mathrm{dS} \cdot \mathrm{m}^{-1}-$ site B). It could indicate that in the coastal shallow zone water heats up quickly and evaporates caused the local increase in salinity concentration. Such process is typical for lagoons.
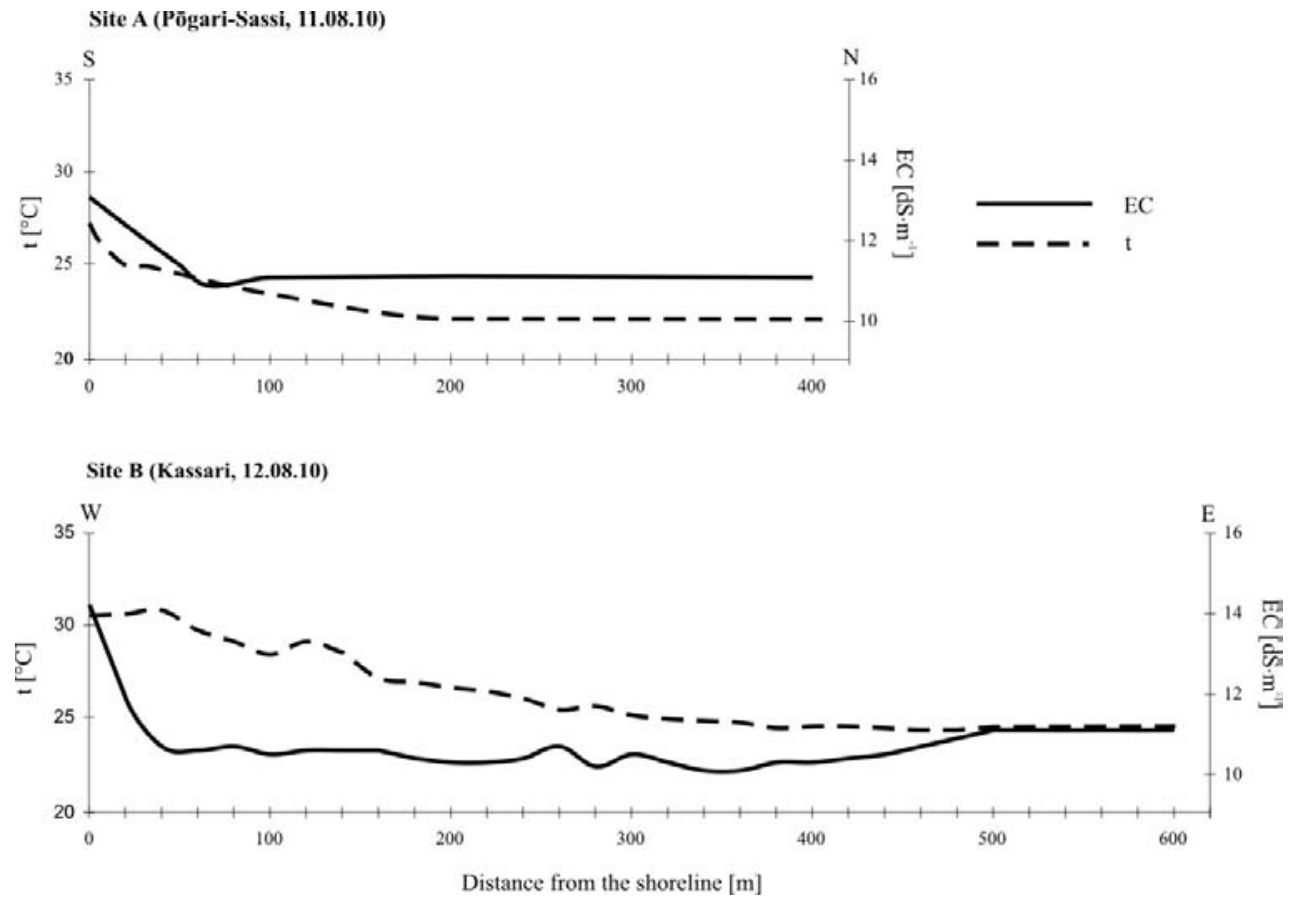

Figure 2. Temperature and salinity of the Baltic Sea water 


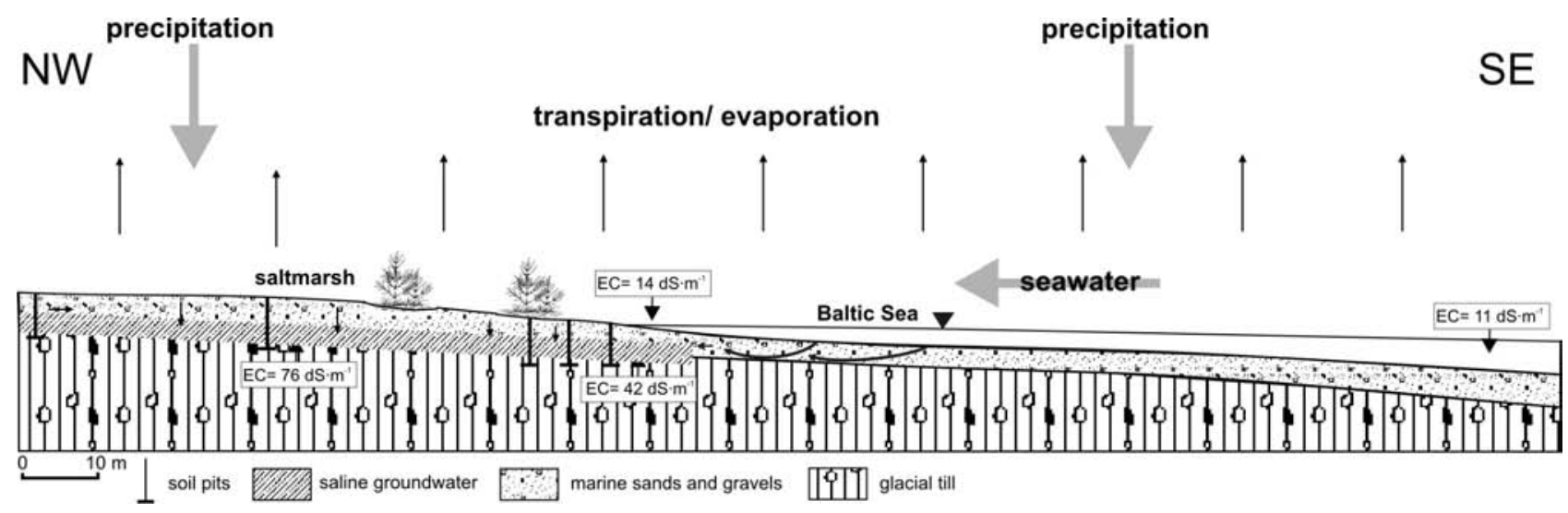

Figure 3. Schematic cross section showing some interactions between abiotic and biotic elements in the Kassari Bay (site B)

Groundwater level was very shallow, respectively $46 \mathrm{~cm}$ (site A) and 30-47 cm (site B) below the soil surface. Water stagnated on the poorly permeable rocks (moraine till). Salinity was very high, several times higher than the salinity of seawater. EC values ranged from 26.7 to $75.5 \mathrm{dS} \cdot \mathrm{m}^{-1}$ (Fig. 3).

Soils of the study areas can be described as Salic Fluvisols (IUSS Working Group WRB 2007). They are characterized by varying amounts of organic matter content in topsoil (0.9-38\%) and distinct variations in salinity level within the profile. Generally, the highest EC values (up to $8.6 \mathrm{dS} \cdot \mathrm{m}^{-1}$ by TDR method) were recorded in the horizons affected by groundwater with the exception of soils located closest to the shoreline.

As described above, specific environmental relationships in the studied coastal lagoons play a fundamental role in the occurrence of common glasswort and also other halophilous plants (Fig. 3). Salicornia europaea was present in the first pioneer vegetation zone next to the sea water table (Fig. 4). This plant was also found growing mostly in small flat depressions (site B), where the water stagnates longer than in adjacent areas. During the June-July-August more than 5 times the Salicornia europaea - sites are under the water during several days. Salicornia europaea was accompanied by Spergularia salina, Glaux maritima, Plantago maritima and Puccinellia maritima. Total vegetation cover in this zone not exceed 5\%. The next zone - salt marsh meadows were dominated by Juncus gerardi but the patches with Salicornia europea were present there as well. The total vegetation cover in this patches was ca. 30-40\% and Salicornia europaea was assessed as abundant with cover $5-10 \%$ (1-2 in Braun-Blanquet scale). In the Salicornia europaea patches Suaeda maritima, Halimone pedunculata, Plantago maritima, Puccinellia maritima, Spergularia salina and Juncus gerardi were noted.

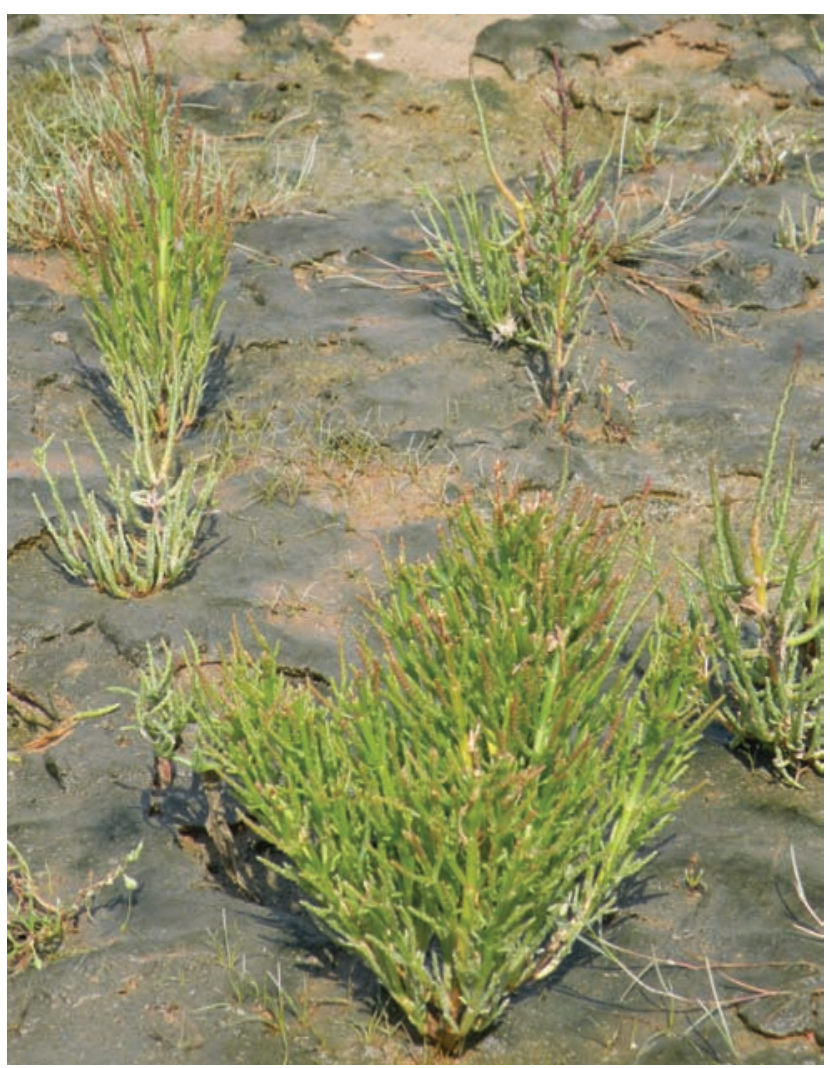

Figure 4. Salicornia europaea growing in the pioneer zone (site B)

\section{Acknowledgements}

This study is the part of interdisciplinary project N305 231135: "Influence of environmental conditions on spatial and temporal differentiation of brackish marsh soils in the 
gradient of Baltic salinity”, financed by Polish Ministry of Science and Higher Education (2008-2011).

\section{References}

Braun-Blanquet J., 1964, Pflanzensoziologie, 3 Aufl., Springer-Verlag, Wien.

IUSS Working Group WRB, 2007, World Reference Base for Soil Resources 2006, first update 2007, World Soil Resources Reports No. 103. FAO, Rome.

Kalm V. \& Kadastik E., 2001, Waterlain glacial diamicton along the Palivere icemarginal zone on the West Estonian Archipelago, eastern Baltic Sea, Proceedings of the Estonian Academy of Sciences, Geology 50 (2): $114-127$.
Kukk T. \& Kull T. (eds.), 2005, Atlas of the Estonian Flora, Tartu.

Mirek Z., Piękoś-Mirkowa H., Zając A. \& Zając M., 2002, Flowering plants and pteridophytes of Poland a checklist, Szafer Institute of Botany, Polish Academy of Science, Kraków.

Suursaar Ü., Otsmann M. \& Kullas T., 2000, Exchange processes in the Väike Strait (Baltic Sea): present, past, future, Proceedings of the Estonian Academy of Sciences, Biology and Ecology 49: 235-252.

Suursaar Ü., 2010, Sea level variations along the Estonian coast of the Baltic Sea, [in:] L. L. Wright (ed.), Sea Level Rise, Coastal Engineering, Shorelines and Tides, Nova Science Publishers, Inc. (in press). 